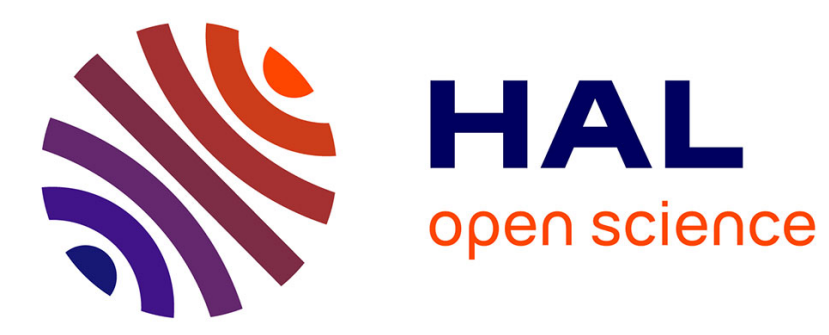

\title{
The Governance of the Knowledge-Intensive Firm in an Industry Life-Cycle Approach
}

Jackie Krafft, Jacques-Laurent Ravix

\section{To cite this version:}

Jackie Krafft, Jacques-Laurent Ravix. The Governance of the Knowledge-Intensive Firm in an Industry Life-Cycle Approach. Mario Morroni. Corporate Governance, Organization and the Firm, Edward Elgar, pp.48-62, 2009, New Perspectives on the Modern Corporation. hal-00239286

\section{HAL Id: hal-00239286 \\ https://hal.science/hal-00239286}

Submitted on 5 Feb 2008

HAL is a multi-disciplinary open access archive for the deposit and dissemination of scientific research documents, whether they are published or not. The documents may come from teaching and research institutions in France or abroad, or from public or private research centers.
L'archive ouverte pluridisciplinaire HAL, est destinée au dépôt et à la diffusion de documents scientifiques de niveau recherche, publiés ou non, émanant des établissements d'enseignement et de recherche français ou étrangers, des laboratoires publics ou privés. 


\title{
The Governance of the Knowledge-Intensive
}

\section{Firm in an Industry Life-Cycle Approach}

\author{
Jackie Krafft and Jacques-Laurent Ravix \\ University of Nice-Sophia Antipolis, CNRS-GREDEG
}

\section{Introduction ${ }^{1}$}

Today, a growing literature develops on the idea that different types of rules and norms should govern differently entrepreneurial and public firms, depending on the industry in which they operate and the stage of development of the industry (Fransman, 2002; Lazonick and O'Sullivan, 2002; Filatotchev and Wright, 2004; Becht, Jenkinson and Mayer, 2005). This chapter contributes to this new literature by adding the empirical dimensions that are pointed out in the industry life cycle (ILC) literature. The purpose is to investigate what the governance of the knowledge-intensive firm may look like in an industry life cycle approach. By knowledge intensive firm, we mean that firms,

\footnotetext{
${ }^{1}$ A preliminary version of this paper was presented at the REF Conference organised in Pisa in June 2007. The work has been carried out with the scientific support of CNRS, and is part of a research project funded by Agence Nationale de la Recherche (contract number: ANR JCJC06_141306). The paper draws on previous contributions: Krafft and Ravix, 2005, 2007, 2008; Dietrich, Krafft, and Ravix, 2008; Ravix, 2008.
} 
independently of their age and size, may be involved in the creation of new knowledge and may be the key actors in the development of innovation processes. As we shall see, the ILC can provide an appropriate, though incomplete, approach to analyse this question. This approach explicitly considers that small new firms enlarge product characteristics and are thus the initiators of innovation in the phases of emergence and growth of the industry, while large mature firms continue the process of innovation by investing in process capacities in the phases of maturity and decline of the industry. In the meantime, this framework is silent on modes of firms governance in relation to the development of the industry. What we think is important is thus to understand how firms governance can stimulate the creation of new knowledge in the early phases of development of the industry, as well as contribute to maintain innovation in the late stages of development of the industry.

In Section 2, we show that when the two sets of literature - firms governance and industry life cycle - are connected, the immediate result is that the governance of firms in the early stages of the life cycle should be different from the governance of firms in the late stages of the life cycle. Firms in the early stages, because they tend to be smaller and younger, should benefit from a mode of governance based on cooperation and assistance to stimulate innovation, while firms in the late stages, because they are often considered as larger, more mature and routinized should be imposed a mode of governance based on control of the manager's action in the interests of shareholders. However, we claim that imposing the knowledge-intensive firms a mode of governance based on control may not be the optimal solution, since we know that this mode of governance favours short term choices that may be detrimental to the development of 
innovation. We advance the idea that new modes of governance should be based on the cognitive nature of the knowledge-intensive firm (large and small, young and old), considered as a distinctive category. In Section 3, we focus on corporate knowledgeintensive firms, the main problem of which is to maintain the cognitive coherence on both the activities of knowledge coordination and knowledge creation. This coherence can be obtained through a mode of corporate governance that we call "corporate entrepreneurship". We analyse its implications on the creation and coordination of new knowledge, and its role in the validation or refutation of innovative conjectures. We then sum up our results and conclude.

\section{The governance of firms in the industry life cycle}

In this section, we analyse the following series of questions: Should firms be owned and managed the same way at the time they emerge, grow, age, and decline? Or should there be distinct types of governance along the phases of the ILC? On the one hand, the literature on start-ups and venture capital suggests that firms should be governed on the basis of a close cooperation between the founder entrepreneur (or professional manager) and the investor (business angel, venture capitalist). On the other hand, the literature on the governance of corporate firms generally supports the shareholder value vision in which the relationship between the manager and the investor are in terms of conflicting objectives, leading to a realignment of the manager's incentives in the investor's interests. The conclusion of these two trends of literature is thus that there should be distinct modes of governance over the ILC, one dedicated to small, young firms, and 
based on cooperation; the other dedicated to older, large and mature firms, and based on control.

\subsection{Cooperative governance of start-ups in the early stages of development}

The ILC gives the small new firms a key role in the impulsion of innovation: they are at the origins of a life cycle (see Klepper, 1997; Gort and Klepper, 1982) ${ }^{2}$. The question of how these firms are financed during the seed phase is thus a key issue. Gompers and Lerner (2001) argue that a venture capital revolution has emerged for these firms. They sustain that (ibid, p. 145): "Venture capital is now an important intermediary in financial markets, by providing capital to firms that might otherwise have difficulty attracting financing. These firms are typically small and young, plagued with high levels of uncertainty and large differences between what entrepreneurs and investors know".

This issue of "what entrepreneurs and investors know" has been treated for a long time in agency terms, i.e. in a framework based on asymmetric information and complete contracts. The manager has important incentives to engage unproductive expenditures, since he does not bear the entire cost of it; or to develop an insufficient level of effort, since this level is not directly observable by the investor. These important information asymmetries between the entrepreneur and the venture capitalist can be solved (Jensen and Meckling, 1976). The solution broadly lies in the investor's scrutinization of firms

\footnotetext{
${ }^{2}$ For surveys on the literature, see also Malerba and Orsenigo (1996); Dosi and Malerba (2002); Krafft (2006).
} 
before providing capital and monitoring them afterwards, especially by participating to the board of directors and defining compensation schemes (including stock options). The outcome is, very often, highly complex venture capital contracts that may be very difficult to define and enforce in the real world, however (Gompers, 1995, 1996; Kaplan and Stroemberg, 2003, 2004)

New developments tend to recognize that the relation between the investor and the manager is necessarily based on incomplete contracts (Hart and Moore, 1988). In that case, what entrepreneurs and investors know is highly dependent on their specific knowledge, skills, experiences, and practices (Audretsch and Lehman, 2006). Since this knowledge is not easily transferable, the investor and the manager have to develop close connections in order to progressively share their respective knowledge. Close connection is especially necessary, since lenders have to face with evaluating innovative but less proven business concepts. Small new firms do not generally demonstrate established history of earning and financial stability. Also, for many start-ups, the primary assets are intangible and difficult to value, thus failing to satisfy requirements for asset-based security. In that case, venture capitalists and business angels finance new and rapidly growing companies, and especially purchase equity securities. But, to do this, they generally assist the development of new products or services, and add value to the company through active participation. They usually take higher risks with the expectation of higher rewards, and have a long-term orientation.

The nature of the relationship between the manager and the investor is thus based on cooperation and assistance: the founder-entrepreneur or the professional manager has 
to diffuse his own knowledge on the characteristics of his innovation and market potentialities, while the business angel or venture capitalist has to propose different solutions to finance the initial step of elaboration of the innovative project, as well as its development over time.

\subsection{Control-based governance of mature firms in the late stages of the ILC}

The ILC also views large firms as key actors in the development of innovation, especially by their greater capacity to invest in process innovation, based on the accumulation of knowledge and competences since their entry at the beginning of the life cycle. However negative effects may also be generated, such as the engagement into inefficient choices from the manager in a situation where large size increases bureaucracy and decreases the intensity of competition. These effects are at the core of the literature on the governance of large, mature firms. In the big corporation, the governance problem is essentially to persuade the manager to behave fairly on behalf of the investor, and to avoid any discretionary behavior. The general solution to this agency problem is to grant managers a highly contingent, long term incentive contract ex ante to align his interests with those of principals (Schleifer and Vishny, 1997). The formalization provides the essential requirements of corporate governance oriented towards shareholder value within a context of transparency of information and generalization of contractual relations in organizations. Managerial corrections may take various forms (board of directors, proxy fights, hostile takeovers, corporate financial structure), and are always oriented towards monitoring and disciplining management in the interest of shareholders and investors. 
The nature of the relationship between the manager and the investor is based on control: the investor orientates and monitors the choices of the manager. The investor, from the information of key indicators such as Return on Investment, or Economic Value Added/ Market Value Added, has the capacity to evaluate whether the manager has behaved fairly to shareholders or not. From these indicators, the investor checks whether the manager has transformed his background knowledge into shareholder value maximizing strategies

\subsection{Firm governance along the different stages of the ILC}

We thus end up with two sets of results: one related to the governance of firms in the early stages, where cooperation and assistance modes of governance should dominate, and one related to the governance in the late stages that should be based on control and realignment of incentives (Figure 1). 
Figure 1: Firm governance along the different stages of the ILC

\section{EARLY STAGES OF THE ILC: EMERGENCE AND GROWTH OF THE INDUSTRY}

Type of firm: Small, new firms

Type of manager: Innovator, Founder Entrepreneur, professional manager

Role of manager: Discover new technological and market opportunities

Type of investor: Business angel, venture capitalist Role of investor: Assist the development of new products or services, Add value to the company through active participation, Take higher risks with the expectation of higher rewards, Have a long-term orientation

Nature of governance: Cooperation and assistance

Structure of governance: Scientific committees,

Research and development committees

\section{LATE STAGES OF THE ILC: MATURITY AND DECLINE OF THE INDUSTRY}

Type of firm: Large, mature firms

Type of manager: Board of directors

Role of manager: Run the company in the interest of the shareholders

Type of investor: Institutional investors (pensio funds)

Role of investor: Realign the manager's incentives Fight against manager's discretion, Assess the valu of the company on the basis financial criteric Minimize risks, Have a short-term orientation

Nature of governance: Control

Structure of governance: Audit committees Compensation systems, proxy fights, hostile takeover

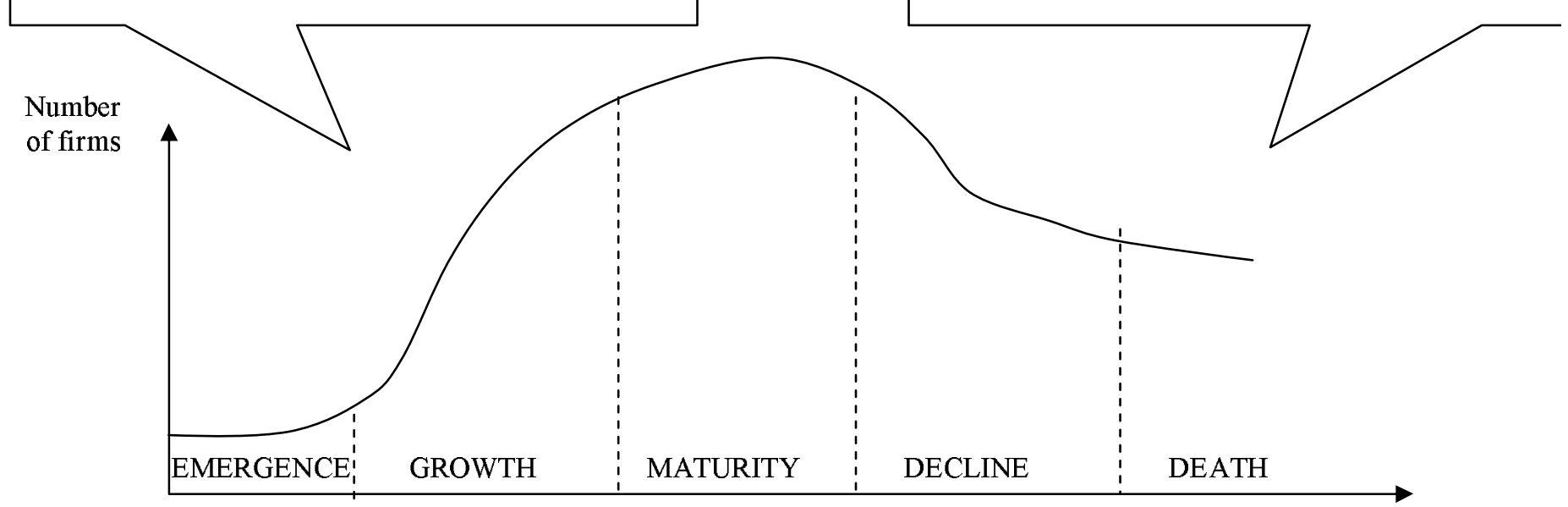

time 
In small new firms that operate in the early stages of the life cycle, the manager is the innovator, the founder entrepreneur or a professional manager, whose role is to discover new technological and market opportunities. The investor is often a business angel or a venture capitalist that assists the development of new products, adds value to the company, takes higher risks with the expectation of higher rewards, and has a long-term orientation. The governance is thus based on cooperation and assistance, and is supported by different structures, such as the development of scientific and R\&D committees, to increase the long term performance of the firm. Alternatively, large and mature firms that dominate the late stages of development of the industry are governed by a board of directors that run the company in the interests of the shareholders. Very often these shareholders are institutional investors, such as pension funds, that tend to realign the managers' incentives, fight against manager's discretion, and assess the value of the company on purely financial criteria. They are short-term and risk minimization oriented.

\section{Corporate governance and the knowledge-intensive firm}

The results obtained in Section 2 on the governance of the firm along the different stages of the life cycle do not tell the complete story. They can be criticised for the

following reasons. First, these results are based on an arbitrary vision of firm, being highly knowledge-intensive at the beginning of their life, and much less as they age. There is no robust evidence on this: a lot of industries are composed of old, large, but still highly innovative companies. Second, if these firms in the late stages of development of an industry are knowledge-intensive, then imposing them a mode of 
governance based on control may not be the optimal solution. This mode of governance favours short term choices that may be detrimental to the development of innovation. Third, the literature on the governance of start ups has greatly changed over time, starting from basic control modes of governance inspired by agency theory, and ending up with more operational and pragmatic modes of governance based on cooperation and assistance. The recognition that knowledge of the manager was necessarily different from - yet highly complementary to - the knowledge of the investor, has been determinant in the change of vision. The argument could thus be logically generalised to the large knowledge intensive firm.

In what follows, we focus on the knowledge-intensive corporation. We argue first that the governance of large corporations involved in innovative activities and sectors cannot be adequately described in agency terms. The governance of knowledge intensive corporations is mainly a matter of cognitive coherence of the firm. In a second step, we generalize the argument made in Section 2 to show how the cooperation and control modes of governance should be articulated in the governance of knowledge-intensive corporations.

\subsection{Governance and cognitive coherence of the firm}

The inadequacy of traditional agency problems

The distinction between information and knowledge, can provide a new rationale to analyse how the predominant thesis on corporate governance based on control has developed, and how this thesis is contested today. The predominant thesis about 
corporate governance is that there should be a superior model promoting optimality by disclosure of information and transparency, and based on control of the manager's actions and its realignment in the interest of shareholders. In this conventional vision of corporate governance, knowledge is assimilated with the manager's private information on his actions and efforts which the investor induces his to reveal through the offering of compensation schemes, e.g. in the form of stock options. Monitoring by boards of directors and large shareholders, and the threat of proxy fights and hostile takeovers can also be implemented to discipline the manager who otherwise might use this information to his own benefit at the expense of the shareholders. In terms of the innovative process, this conventional vision supports the belief that new activities and competences can mainly be acquired externally, e.g. by means of mergers and acquisitions.

Today, this thesis is contested, since the adoption of a unique and universal best practice neglects the diversity and heterogeneity of firms, industries, as well as institutional contexts (Becht, Jenkinson and Mayer, 2005). Moreover, evidence shows that the conventional model of governance tends to generate major failures and turbulences, especially in knowledge intensive industries (Fransman, 2002; Lazonick and O'Sullivan, 2002). Another strand of literature tends to show that this conventional model is not appropriate to the governance of knowledge-intensive firms: the cooperative theory of the Japanese firm argues that the manager is at the centre of the cooperative game relating shareholders and employees (Aoki, 1984), the stakeholder perspective on corporations generalizes the argument to every partner entitled to be residual claimant (Donaldson and Preston, 1995; Blair, 1995), the critical resource theory insists on the 
centrality of the manager as a coordinator of firm's activities (Rajan and Zingales, 1998; Zingales, 2000), the entrepreneurial learning approach contrasts with the usual vision of the entrepreneur as an empire builder (Klein and Klein, 2002; Ellig, 2002).

We can draw from this that agency problems based on the traditional ownership-control distinction and the need to monitor managerial discretion do not fit in with knowledgeintensive firms for the following reasons: human assets are crucial in the development

of knowledge-intensive firms whereas physical assets can be replaced easily; in knowledge-intensive firms the value of human capital is increasing, leading to greater independence for individual workers and more opportunity for job mobility, while financial innovations are enabling easier access to capital markets for individual entrepreneurs. Likewise, mergers and acquisitions, takeovers, and LBOs are instruments for rationalizing the structure of the industry rather than mechanisms for disciplining managers or means for acquiring externally innovative activities and competences.

\section{The cognitive firm}

However, the literature referred to above does not clearly identify corporate governance principles. In that purpose one needs to refer to a cognitive vision of the corporate firm (O'Sullivan, 2000; Foss, Christensen, 2001). This states that large modern firms are mainly considered to be structures of innovative resource allocation and complementary knowledge assets involved in collective learning processes. Innovative resource allocation involves irreversible commitments of resources for uncertain returns, organization of the collective learning process, and strategic decisions as creative response to existing conditions (O'Sullivan, 2000). Corporate firms have to solve two 
main problems: the problem of "knowledge dispersal" among the different actors of the firm, and the innovative problem of "knowledge creation", which calls for new combinations of knowledge and learning (Foss \& Christensen, 2001, p.222). When problems of change are put centre stage in the analysis, the real determinant of firm governance should be the presence or absence of innovation. The absence of innovation could legitimate the 'control' mode of governance in routinized firms, independent of their age or size, while the 'cooperation and assistance' mode must be the key reference when innovation is a central concern for the firm. A cognitive vision of the corporate firm leads to a new interpretation of the relationships among shareholders and managers, based on the notion of corporate entrepreneurship, in which the cooperation and control modes of firm governance intervene in a sequential timing.

\section{Corporate entrepreneurship}

Managerial control is useful in knowledge-intensive firms in so far as it is considered to be an entrepreneurial activity creating diversity, i.e. creating new assets and competences in new business and experimenting in new directions in existing business To focus on the cognitive coherence of the firm challenges the notion of corporate governance based on agency problems, i.e. conflicts of interest involving members of the organization, especially owners and managers. When knowledge is a key element, the real determinant of the co-evolution of financial dynamics and industrial dynamics is how knowledge is coordinated among investors and managers, and how these actors arrive (or not) at a cognitive coherence through corporate governance. 
In knowledge-intensive firms, both managers and investors are jointly committed to develop an entrepreneurial behavior favoring long term perspective, knowledge creation and coordination for innovative purpose, and implying the acceptance of greater uncertainty and higher risk-taking. In that perspective, corporate governance is dedicated to the coordination of learning processes, meaning that corporate governance and the governance of knowledge are two facets of the development and coherence of the firm (Penrose, 1959; Foss, Christensen, 2001)

This mode of corporate governance has been analyzed by referring to the notion of "corporate entrepreneurship". We define corporate entrepreneurship as a hybrid form of corporate governance mixing the cooperation and control modes described earlier in Section 2. Managers, by defining and selecting innovative processes, and investors, by determining the money that is invested to sustain these processes, both take part to the creation and governance of new knowledge by the firm. Cooperation must exist between managers and investors, since they collectively contribute to corporate development and coherence. Only in a second step does control occur: the investor reacts to the innovative choice, by comforting or refuting the innovative conjecture.

\subsection{Cooperation and control as related modes of governance in the knowledge- intensive firm}

Cooperation for the creation and coordination of knowledge

Long term innovation affects corporate coherence, since it involves important reconfigurations of resources and competencies over time (Chatterjee, Wernerfelt, 1991; 
Foss, 1993; Teece, Pisano, 1994; Teece, Pisano and Shuen, 1997; Piscitello, 2004). As we argued above, in order to preserve corporate coherence in an innovation context, two sets of problems have to be solved (Foss, Christensen, 2001). The first problem is that of knowledge creation, i.e. how knowledge arises from new combination, and from the discovery of new complementarities between existing stocks of knowledge and experimentation of new learning processes. The second problem is that of coordination of knowledge dispersal, that goes together with the specialization of tasks in large corporations, and involves efforts in constructing shared cognitive patterns.

The role of the manager is crucial in solving these two sets of problems. First, because managerial control has a basic facet of stimulating the entrepreneurial activity of the different stakeholders within the firm, but also among the network of innovation partners, that favours knowledge creation. Second because managerial control also involves command, management information systems, corporate routines and corporate cultures, that can act as knowledge coordination. In order to maintain corporate coherence, the manager has a key role to play in the achievement of a critical mass of stakeholders (at the level of the firm and also at the level of the network) playing the long term innovative strategy, while refraining the temptation of predator behaviours in the meantime.

The investor also is highly involved in the process. Investors have to develop new competences and experience in the evaluation of long-term innovative companies, since usual market criteria essentially refer to tangible assets and require long term track records that are often neither applicable nor available in highly innovative contexts. In 
that perspective, the valuation of intangibles by investors becomes a real issue: valuation is the outcome of a process of coordination of different elements of knowledge related to the perceived ability of the firm to create new technological and market opportunities; valuation is also a key element in sustaining some innovative projects (and not others) that shape the evolution of the industry.

Corporate entrepreneurship means that managers and investors are mostly intertwined ex ante in the process of solving corporate coherence problems in the modern cognitive firm. Each actor is endowed with a different piece of knowledge that has to be recombined in a process of collective learning oriented towards corporate development. The manager brings his own competences on the development of learning processes by creating diversity, exploring new opportunities, and providing continuity in innovation. The investor also contributes to the development of learning processes by providing the manager his own skills and experiences on the financial feasibility of external restructurings (M\&As, cooperation), or internal strategies (compensation plans, reporting activities, information systems). Cooperation between managers and investors favours the processes of creation and coordination of new knowledge that are engaged in a long-term innovative context. But the investor also has to control ex post the impact of innovative choices implemented in the company.

\section{Control to comfort or refute the innovative conjecture}

If initially long term innovation greatly disturbs corporate coherence, one should expect over time that corporate coherence is improved. Here thus, control must be operated to guarantee that coherence is restored or at least evolves towards a reasonable level. 
The manager has to provide the investor with regular information (documents, reports, etc.) explaining whether the innovative strategy impacts corporate coherence and how. If after a sufficiently long time span, the innovative strategy generates new knowledge but insufficiently coordinated, or if the critical mass of efforts is not obtained and that stakeholders massively turn to adopt an alternative strategy, then the manager and the investor can jointly infer that erroneous decisions were implemented during the innovation process. The investor checks ex post that the manager implements the productive and organizational decisions (cooperation agreements or M\&As within the innovation network) dedicated to sustain the critical mass of efforts, and further the long term innovative strategy. Contrary to shareholder value maximization principles, the problem of the investor is not to limit the discretionary power of the manager but, rather, to control this power. Especially, the investor has to control the manager's trustworthiness, and eventually his propensity to "empire building", in reference to his ability or inability to restore corporate coherence after the engagement of a long term innovative strategy. When innovation is concerned, thus, the issue is not to impose drastic changes in strategies based on the belief that what the investor (respectively the manager) knows is always right. Rather, the issue is to control that innovation is developed and that corporate coherence is progressively restored.

\section{The governance of knowledge-intensive firms along the industry life cycle}

Corporate governance as well as the governance of small knowledge-intensive firms is thus constructed step by step with an ex ante process of collective learning, and an ex post process of control, in which each actor embodies a piece of diversified and specialized knowledge related to their respective domains and fields of experience, that 
has to be recombined and used to stimulate corporate development. Figure 2 provides more details on the governance of knowledge-intensive firms.

Figure 2: The governance of the knowledge-intensive firm along the ILC

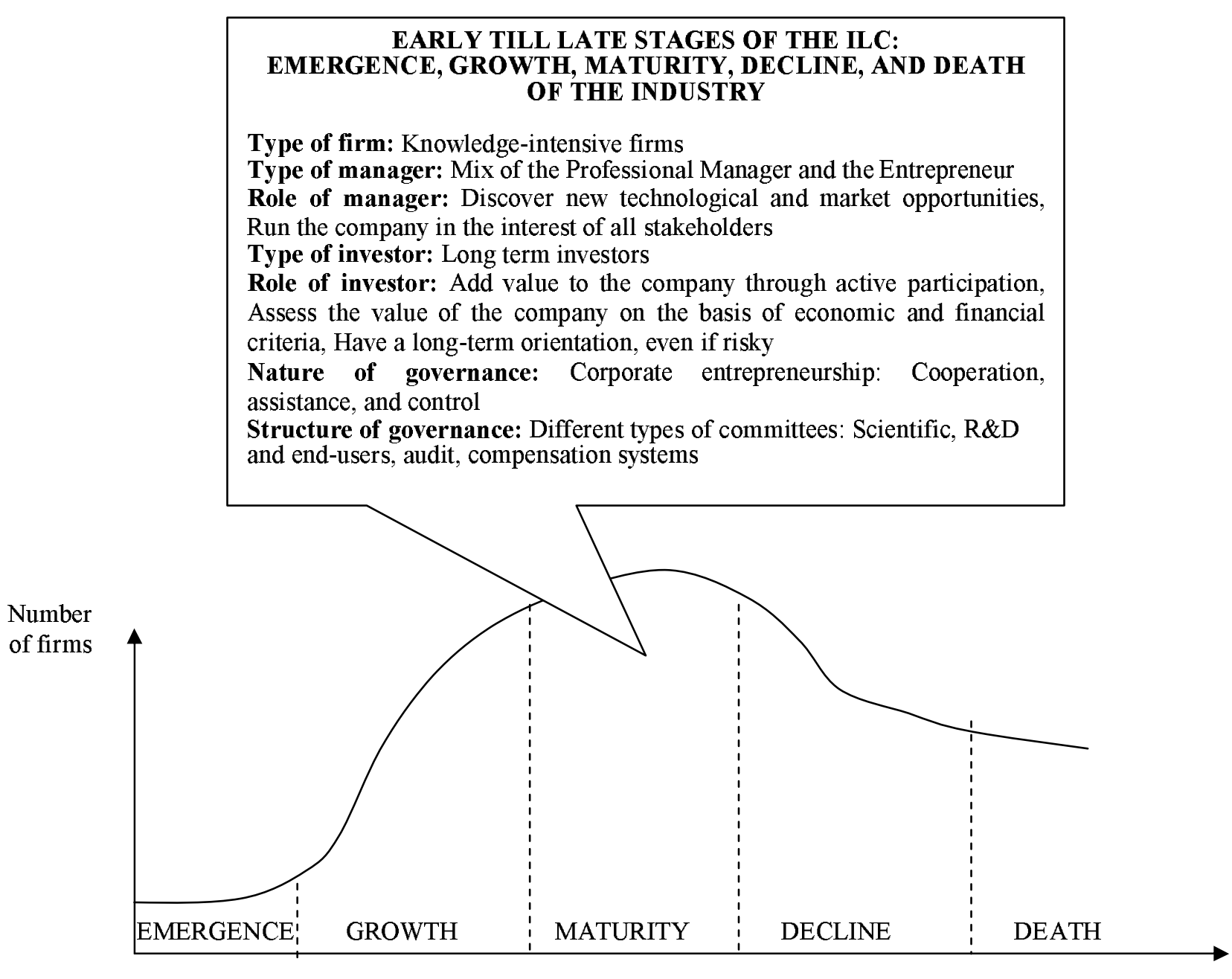


Principle of governance concern here knowledge-intensive firms, independently of their age and size. The manager has the double role to act as a professional manager and as an entrepreneur, which means that he has to run the company in the interests of all the stakeholders that contribute to the value of the firm, and also to discover new technological and market opportunities by the active involvement of all stakeholders in learning processes. The investor has to develop a long term orientation, and is deemed to assess the value of the company on the basis of economic and financial criteria. Cooperation and assistance between the manager and the investor (business angel, venture capitalist or major shareholder) must dominate, on the basis of specific structures of governance favouring common learning processes. One could for instance think about scientific, R\&D or end-users committees as structures of governance of this kind. In the meantime, control also has to occur on the basis of more traditional structures of governance, such as audit and compensation systems.

\section{Conclusion}

This chapter was intended to analyse the governance of the knowledge-intensive firm in an industry life cycle approach. It has been shown that a simple connection between the literature on the governance of firms and the industry life cycle was not sufficient to analyse this question. The reason is that the outcome of this simple connection promotes a mode of governance based on cooperation and assistance for small, young firms and a mode of governance based on control for corporate firms. We explain that this dichotomic model of governance is not appropriate to knowledge-intensive firms that stimulate the creation of new knowledge in the early stages of development of the 
industry, but still have to maintain innovation in the late stages of development of the industry. We advance that this cannot be guaranteed if the mode of governance is exclusively based on control. We thus elaborate new principles of governance for knowledge-intensive firms (i.e. the "corporate entrepreneurship") that favour the cognitive coherence of their activities of knowledge coordination and knowledge creation.

\section{References}

Aoki, Masahiko (1984), The Cooperative Game Theory of the Firm, Oxford: Oxford University Press.

Audretsch, D. and E. Lehmann (2006), 'Entrepreneurial Access and Absorption of Knowledge Spillovers: Strategic Board and Managerial Composition for Competitive Advantage', Journal of Small Business Management, 44(2), 155166

Becht, M., Jenkinson, T. and C. Mayer (2005), 'Corporate governance: an assessment', Oxford Review of Economic Policy, 21(2), 155-163.

Blair, Margaret (1995), Ownership and Control: Rethinking Corporate Governance for the Twenty Fisrts Century, Washington: Brookings Institution Press.

Chatterjee, S. and B. Wernerfelt, (1991), 'The link between resources and type of diversification: theory and evidence', Strategic Management Journal, 12(1), 3348.

Dietrich, M., Krafft, J. and J.L. Ravix (2008), 'The governance and regulation of the firm - Special issue', International Review of Applied Economics, 22(2/3), forthcoming. 
Donaldson, T. and L. Preston (1995), 'The stakeholder theory of corporation: concepts, evidence and implications', Academy of management Review, 20(1), 65-91.

Dosi, L. and F. Malerba (eds) (2002), 'Special issue: interpreting industrial dynamics 20 years after Nelson and Winter's Evolutionary Theory of Economic Change', Industrial and Corporate Change, 11(4), 3-202.

Ellig, J. (2002), 'Telecommunication mergers and theories of the firm', in Nicolaï Foss, and Peter Klein (eds.), Entrepreneurship and the Firm: Austrian Perspectives on Economic Organization, Cheltenham: Edward Elgar.

Filatotchev, I. and M. Wright (eds) (2004), The Life-Cycle of Corporate Governance, Cheltenham: Edward Elgar.

Foss, N. (1993), 'Theories of the firm: competence and strategy perspectives', Journal of Evolutionary Economics, 3(2), 127-144.

Foss, N. and J. Christensen (2001), 'A market process approach to corporate coherence', Managerial and Decision Economics, 22(4-5), 213-226.

Fransman, M. (2002), Telecoms in the Internet Age: From Boom to Bust to..., Oxford University Press: Oxford.

Gompers, P. (1995), 'Optimal Investment, Monitoring, and the Staging of Venture Capital', Journal of Finance, 50(5), 1461-1490.

Gompers, P. (1996), 'Grandstanding in the venture capital industry', Journal of Financial Economics, 42(1), 133-156.

Gompers, P. and J. Lerner (2001), 'The Venture Capital Revolution', Journal of Economic Perspectives, 15(2), 145-168.

Gort, M. and S. Klepper (1982), 'Time paths in the diffusion of product innovations', Economic Journal, 92(367), 630-653. 
Hart, O. and J. Moore (1988), 'Incomplete contracts and renegociation', Econometrica, 56(4), 755-786.

Jensen, M. and W. Meckling (1976), 'Theory of the firm: managerial behaviour agency costs and ownership structure', Journal of Financial Economics, 3(4), 305-360.

Kaplan, S. and P. Stroemberg (2003), 'Financial Contracting Theory Meets the Real World: An Empirical Analysis of Venture Capital Contracts', Review of Economic Studies, 70(243), 281-315

Kaplan, S. and P. Stroemberg (2004), 'Characteristics, Contracts, and Actions: Evidence from Venture Capitalist Analyses', Journal of Finance, 59(5), 21772210.

Klein, P. and S. Klein (2002), 'Do entrepreneurs make predictable mistakes? Evidence from corporate divestitures', in Nicolaï Foss and Peter Klein (eds.), Entrepreneurship and the Firm: Austrian Perspectives on Economic Organization, Edward Elgar: Cheltenham.

Klepper, S. (1997), 'Industry Life Cycles', Industrial and Corporate Change, 6(1), 119143.

Krafft, J. (2006), 'What do we know about Industrial Dynamics? Introduction to the Special Issue', Revue de l'OFCE, june.

Krafft, J. and J.L. Ravix (2007), 'The Firm and its governance over the industry lifecycle', Corporate Ownership and Control, 5(1), pp.233-242.

Krafft, J. and J.L. Ravix (2005), 'The governance of innovative firms: an evolutionary perspective', Economics of Innovation and New Technology, 14(3), 125-148. 
Krafft, J. and J.L. Ravix (2008), 'Corporate governance and the governance of knowledge: rethinking the relationship in terms of corporate coherence', Economics of Innovation and New Technology, 17(1-2), 79-96.

Lazonick, W. and O'Sullivan, M. (eds), 2002, Corporate Governance and Sustainable Prosperity, New York: Palgrave.

Malerba, F. and L. Orsenigo (1996), 'The dynamics of evolution of industry', Industrial and Corporate Change, 5(1), 51-87.

O'Sullivan, M. (2000), 'The innovative enterprise and corporate governance', Cambridge Journal of Economics, 24(4), 393-416.

Penrose, E. (1959), The Theory of the Growth of the Firm, Basil Blackwell, London.

Piscitello, L. (2004), 'Corporate diversification, coherence and economic performance', Industrial and Corporate Change, 13(5), 757-787.

Rajan, R. and L. Zingales (1998), 'Power in a theory of the firm', Quarterly Journal of Economics, 113(2), 387-432

Ravix, J.L. (2008), 'Nature and governance of the firm: in search of an integrated perspective', International Review of Applied Economics, 22(2/3), forthcoming.

Schleifer, A. and R. Vishny (1997), 'A survey on corporate governance', Journal of Finance, 52(2), 737-783.

Teece, D. and G. Pisano (1994), 'The dynamic capabilities of firms: An introduction', Industrial and Corporate Change, 3(3), 537-556.

Teece, D., Pisano G. and A. Shuen (1997), 'Dynamic capabilities and Strategic Management', Strategic Management Journal, 18(7), 509-533.

Zingales, L. (2000), 'In search for new foundations', Journal of Finance, 55(4), 1623 1653 